УДК 314.748 (477)

DOI: https://doi.org/10.37320/2415-3583/8.16

Черненко Н.О.

кандидат економічних наук, доцент, доцент кафедри міжнародної економіки, Національний технічний університет Украйни «Київський політехнічний інститут імені Ігоря Сікорського»

Зінченко Л.А. студентка кафедри міжнародної економіки, Національний технічний університет Украӥни «Київський політехнічний інститут імені Ігоря Сікорського»

\title{
РОЗВИТОК ТУРИЗМУ ЯК ПРІОРИТЕТНОЇ ГАЛУЗІ ЕКОНОМІКИ
}

У статті проаналізовано сучасний стан розвитку туризму як пріоритетної галузі економіки. Визначено сутність економічної категорї туризму та його значення для розвитку економіки. У статті зазначено, щзо Украӥна володіє значним туристичним потенціалом і має всі передумови для розвитку внутрішнього, в 'їного та виїзого туризму. Проаналізовано статистичні дані щзоо розвитку туристичної діяльності України, а саме динаміку туристичного потоку іноземних громадян до України та украӥниів, які виїжджали за кордон, динаміку прямоі зайнятості населення в галузі туризму, динаміку частки туристичної галузі у ВВП Украӥни, динаміку обсягів державного фінансування туризму. Встановлено, щчо в Україні протягом 2013-2019 рр. відбувалися скорочення обсягів туристичного потоку та зниження темпів зростання галузі туризму. На основі аналізу показників розвитку туристичної галузі визначено основні напрями розвитку туризму в Украӥні.

Ключові слова: галузь туризму, туристичні потоки, фактори впливу, туристична діяльність, напрями розвитку галузі туризму.

Постановка проблеми. Економіка України спрямована на активну інтеграцію у світове господарство, тому туристична галузь поступово перетворюється на чинник соціально-економічного розвитку країни, проте темпи цих перетворень залишаються незадовільними, про що свідчать найнижчі позиції у світових рейтингах туристичного ринку. Україна володіє значним туристичним потенціалом і має всі передумови для розвитку внутрішнього, в'їзного та виїзного туризму, зокрема унікальні природні ресурси, сприятливий клімат, комплекс історико-культурних та архітектурних пам'яток, об'єктів рекреаційного призначення. Ці обставини обумовлюють необхідність удосконалення методів розвитку галузі туризму в Україні.

Аналіз останніх досліджень і публікацій. В економічній літературі існує багато поглядів на поняття «туризм», зокрема як на галузь економіки або міжгалузевий комплекс, як на ринок, на якому туристичне підприємство 3 продукції різних галузей формує туристичний продукт, як на будь-яку подорож задля відпочинку та знайомства з новими регіонами й об'єктами. Вивченням проблеми розвитку туризму займалися такі вітчизняні вчені, як С.М. Домбровська, С.О. Гуткевич, Є.В. Козловський, О.А. Мельниченко, В.О. Шведун. Сучасний стан міжнародного туристичного потоку в Україні характеризується зменшенням обсягів міжнародних туристів та зниженням темпів розвитку туристичної галузі. Значна частина природних територій та об'єктів культурної спадщини непристосована для туристичних відвід- увань, туристична інфраструктура загалом не відповідає світовим стандартам якості, а туристичні послуги - вимогам до якості обслуговування, тому існує необхідність розроблення стратегії розвитку галузі туризму в Україні.

Мета статті полягає в аналізі теоретичних положень та основних показників стану розвитку галузі туризму в Україні. Результатом роботи $€$ розроблення стратегії розвитку туристичної галузі України відповідно до європейських стандартів та світового досвіду.

Виклад основного матеріалу. Туризм як пріоритетна галузь вивчається та трактується багатьма вченими залежно від мети використання, а саме наукової чи практичної. Нами проведено аналіз сутності туризму як економічної категорії, визначено, що найбільш точне й повне визначення туризму представлене в Законі України «Про туризм» (1995р.): тимчасовий виїзд осіб із постійного місця проживання 3 пізнавальною, оздоровчою, професійноділовою, спортивною та іншою метою на термін від 24 годин до одного року без зайняття оплачуваною діяльністю в місці тимчасового перебування [1].

Як галузь туризм має певні особливості, а саме орієнтація на ресурси під час розміщення туристичних підприємств; сезонність виробництва туристичних послуг; залежність якості туристичних послуг від обслуговуючого персоналу; нерозривний процес виробництва та споживання туристичного продукту; використання в комплексі декількох різновидів рекреаційних ресурсів; різна тривалість туристичних послуг. 
На основі аналізу сутності туризму як економічної категорії визначено, що туризм виконує такі функції, як економічна (збільшує надходження до бюджету країни), рекреаційна (відновлення фізичних і психічних сил), оздоровча (покращення стану здоров'я в результаті туристичних поїздок), духовна, гуманітарна, соціально-культурна, виховна, екологічна (формування екологічної свідомості серед туристів), політична (створення сприятливого іміджу країни за кордоном), навчальна (пізнавання світу, набуття досвіду), етнічна (приїзд емігрантів або їх нащадків до країни предків) [2].

Одним 3 найважливіших показників туристичної діяльності є обсяг туристичного потоку, який відображає напрями міжнародної туристичної взаємодії. Динаміка туристичного потоку характеризує ступінь відкритості національної економіки, характер суспільно-політичних та економічних перетворень, інвестиційну привабливість країни тощо.

На сучасному етапі розвитку зовнішній туризм, а саме виїзд українців за кордон, розвивається швидкими темпами, що певним чином пов'язане 3 безвізовим режимом. Так, кількість громадян України, які виїжджали за кордон, протягом 2000-2007 рр. постійно зростала. У 2008 р. відбувся незначний спад туристичного потоку з України, а саме на 10,6\% (у 2007 р. кількість туристів 3 країни становила 17334 млн. осіб, а у 2008 р. - 15498 млн. осіб). Кількість туристів, які виїжджали з країни, у 2010 р. знову почала зростати (у 2009 р. кількість туристів становила 15333 млн. осіб, а у 2010 р. - 17180 млн. осіб). Мінімальною кількість осіб, які виїжджали за кордон, була у 2000 р., а саме 13422 млн. осіб, максимальною кількість осіб, які виїжджали за кордон, була у 2017 р., а саме 26437 млн. осіб.

Сучасний стан міжнародного туристичного потоку до України характеризується зменшенням обсягів міжнародних туристів та зниженням темпів розвитку туристичної галузі. На основі аналізу кількості туристів визначено, що протягом 2000-2008 рр. обсяг в їзного туристичного потоку до України стабільно зростав, але 3 2009 р. відбувся різкий спад туристичного потоку. Так, якщо у 2000 р. до України в'їхали 6 млн. іноземних туристів, у 2008 р. - 25 млн. осіб, то у 2009 р. Україну відвідали всього 20 млн. осіб. Деяке уповільнення темпів зростання протягом 2009 р. пов'язують із внутрішніми організаційно-економічними та політичними чинниками. У 2012 р. кількість міжнародних туристів зросла до 23 млн. осіб, що пов'язано 3 проведенням в Україні фінальної частини чемпіонату Європи 3 футболу «Свро - 2012». Значні зміни відбулись у 2014 р. Кількість іноземних відвідувачів України скоротилася майже на 12 млн. осіб (-48,5\%) і становила 12711 млн. осіб.

Максимальною кількість осіб, які відвідали Україну, була у 2008 р., а саме 25449 млн. осіб, мінімальною кількість осіб, які відвідали Україну, була у 2014 р., а саме 12711 млн. осіб [3].

Географічна структура міжнародних туристичних прибуттів в Україну протягом 2000-2017 pp. постійно змінювалась. Так, до 2014 р. найбільша частка іноземців, які приїжджали до України, стабільно припадала на Росію. Військово-політична агресія Росії вплинула на значне скорочення кількості туристів 3 цієї країни: якщо у 2010 р. кількість іноземців становила 7,9 млн. осіб, то у 2014 р. - всього 2,3 млн. осіб, частка туристів 3 Польщі у 2014 р. порівняно з 2010 р. скоротилась на 46,2\%, з Угорщини - на 7,5\%, з Білорусі - на $47,9 \%$, а з Молдови збільшилась на 7,5\%. В сучасних умовах економічного та політичного стану кількість туристів 3 країн-сусідів характеризується такими показниками: у 2017 р. порівняно 3 2014 р. кількість туристів з Польщі збільшилась на $1,8 \%, 3$ Угорщини - на $28,1 \%$, 3 Білорусі - на

Таблиця 1 - Динаміка в'їзду іноземних громадян в Україну за країнами, 3 яких вони прибули (2010 р., 2014 р., 2017 р.), осіб

\begin{tabular}{|c|c|c|c|c|c|}
\hline \multirow{2}{*}{ Рік } & \multicolumn{5}{|c|}{ Країни } \\
\cline { 2 - 6 } & Росія & Молдова & Білорусь & Польща & Угорщина \\
\hline 2010 & 7900436 & 4063459 & 3058023 & 2089647 & 944777 \\
\hline 2014 & 2362982 & 4368355 & 1592935 & 1123945 & 874184 \\
\hline 2017 & 1464764 & 4435664 & 2727645 & 1144249 & 1119446 \\
\hline Tр 2017/2010, \% & 18,5 & 109,1 & 89,2 & 54,8 & 118,5 \\
\hline$\Delta \mathrm{T} \mathrm{2017/2010}$ & -6435672 & 372205 & -330378 & -945398 & 174669 \\
\hline Тр 2017/2014,\% & 62 & 101,5 & 171,2 & 101,8 & 128,1 \\
\hline Тпр 2017/2014,\% & -38 & 1,5 & 71,2 & 1,8 & 28,1 \\
\hline$\Delta$ Т 2017/2014 & -898218 & 67309 & 1134710 & 20304 & 245262 \\
\hline Тр 2014/2010,\% & 29,9 & 107,5 & 52,1 & 53,8 & 92,5 \\
\hline Тпр 2014/2010,\% & $-70,1$ & 7,5 & $-47,9$ & $-46,2$ & $-7,5$ \\
\hline$\Delta$ Т 2014/2010 & -5537454 & 304896 & -1465088 & -965702 & -70593 \\
\hline
\end{tabular}

Позначення: $\mathrm{Tp}$ - темп росту, Тпр - темп приросту, $\Delta \mathrm{T}$ - абсолютна різниця

Джерело: розроблено авторами на основі джерела [3] 
71,2\%, з Молдови - на 1,5\%, а з Росії скоротилась на 38\%. У 2017 р. порівняно з 2010 р. скоротилась кількість туристів з Росії в 5,3 разів, з Білорусії - в 1,12 разів, 3 Польщі - в 1,82 рази, а з Молдови та Білорусії зросла у 0,9 та 0,84 разів відповідно [3].

Загальна кількість зайнятих у галузі туризму у 2014 р. становила 1,27 млн. осіб (6,4\% загальної кількості працівників), у 2015 р. цей показник збільшився до 1,29 млн. осіб, тобто на 1,3\% (6,5\% загальної кількості працівників). У 2017 р. загальна кількість зайнятих у галузі туризму становила 856 тис. осіб (5,1\% від загальної кількості працівників), що на 50,7\% менше порівняно 3 2015 р. У 2018 р. порівняно 32017 р. загальна кількість зайнятих у туризмі зросла на 6,14\% i становила 910,5 тис. осіб, або 5,3\% від загальної кількості працівників [4].

Аналіз частки туристичної галузі у ВВП України протягом 2013-2017 pр. показав, що найбільшою частка туристичної галузі у ВВП країни була у 2013 р., коли вона становила 2,3\%. У 2014-2016 рр. відбувся спад до 1,42\%, у 2017 р. - незначне зростання $(0,10 \%)$. На це впливає політична ситуація в країні, а саме проведення військових дій [5].

Фінансове забезпечення туристичної галузі це створення сприятливого середовища щодо виді- лення, розподілу та залучення фінансових ресурсів для розвитку галузі туризму.

Аналіз обсягів державного фінансування галузі туризму в Україні (рис. 3) показав, що протягом 2012-2014 рр. обсяг державного фінансування галузі туризму поступово скорочувався, а у 2015 р. та 2016 р. до Державного бюджету України не було закладено коштів для фінансової підтримки розвитку туризму, тому що на території України розпочались воєнні дії, отже, кошти спрямовувались на підвищення обороноздатності армії.

До 2015 р. фінансування галузі туризму здійснювалось через Державне агентство $з$ туризму та курортів, а 32017 р. фінансування галузі туризму здійснюється через Департамент туризму та курортів Міністерства економічного розвитку та торгівлі. У 2017 р. Державний бюджет України передбачав фінансову підтримку галузі туризму в обсязі 30,486 млн. грн., у 2018 р. цей показник скоротився на 9,32\% і становив 27,866 млн. грн., у 2019 р. витрати на розвиток галузі туризму становлять 17,866 млн. грн., що на 56\% менше порівняно 32018 р. [6].

Важливим об'єктом для розвитку туризму та залучення міжнародних туристів є пам'ятки iсторії, архітектури, археологіі, етнографічні особливості територій. Україна є однією 3 про-

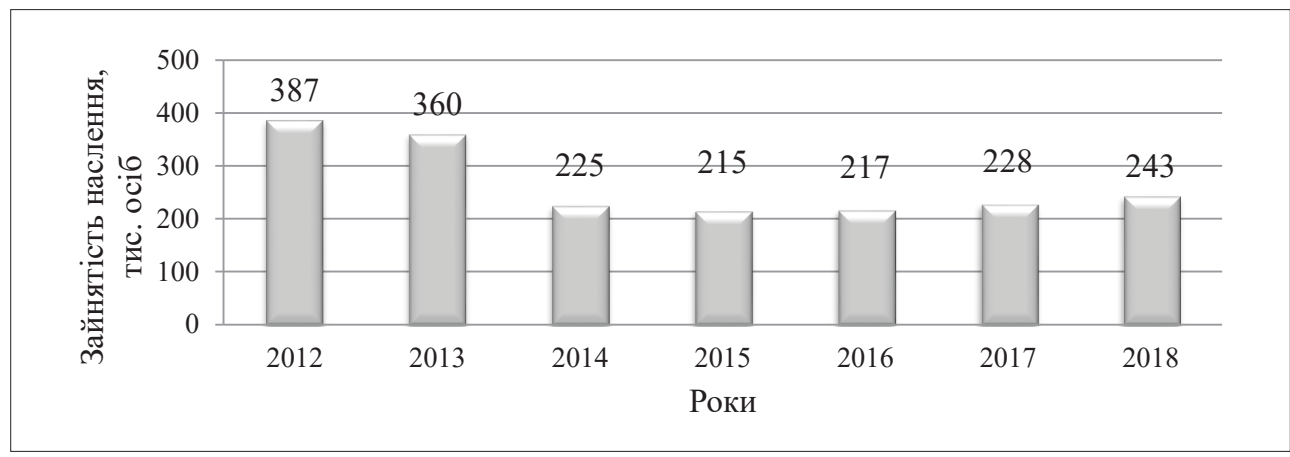

Рисунок 1 - Загальна кількість зайнятих у галузі туризму України Джерело: розроблено авторами на основі джерела [4]

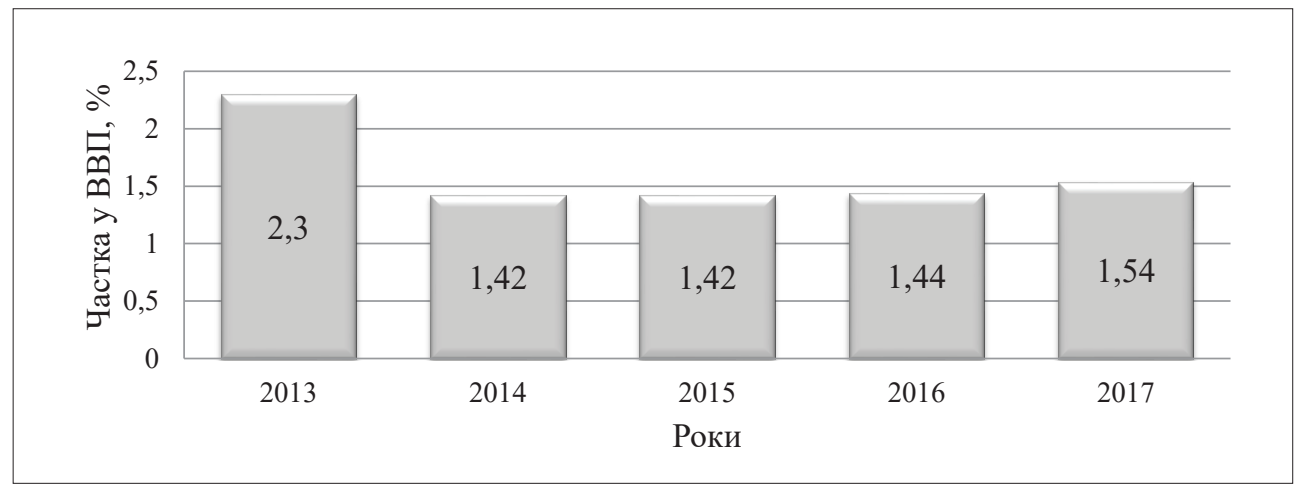

Рисунок 2 - Динаміка частки туристичної галузі у ВВП України, \% Джерело: розроблено автором на основі джерела [5] 


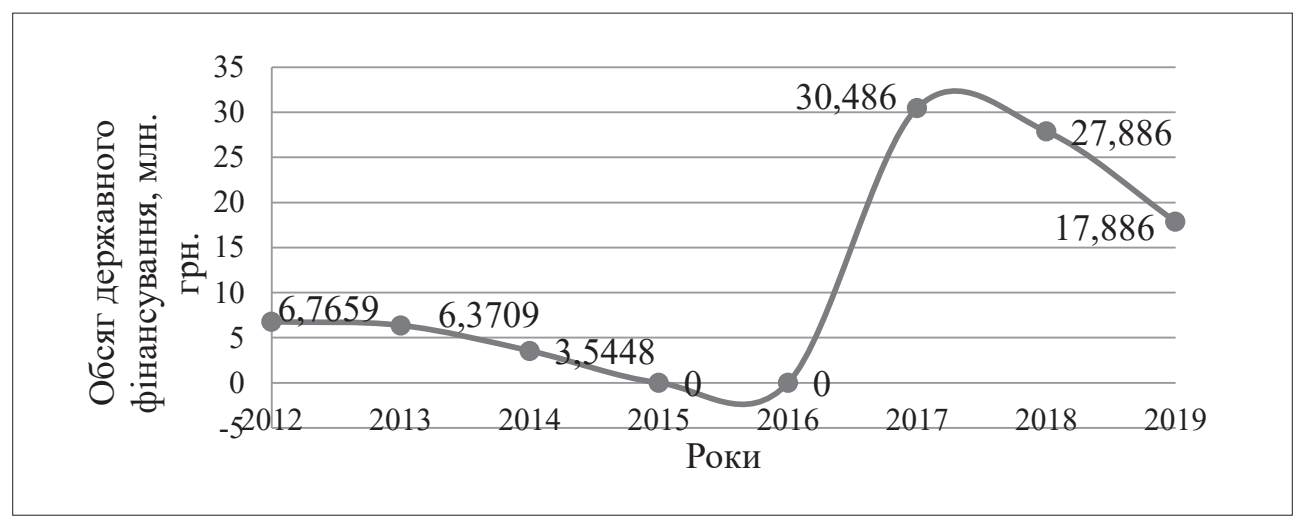

Рисунок 3 - Динаміка обсягів державного фінансування туризму, млн. грн.

Джерело: розроблено автором на основі джерела [6]

відних країн Європи за кількістю об'єктів історико-культурної спадщини. За даними Міністерства культури України на державному утриманні перебувають 150 тис. нерухомих пам'яток історії та культури, зокрема 57206 пам'яток археології, 51364 пам'ятки історії, 16800 пам'яток архітектури та містобудування, близько 200 замків [7].

Україна володіє культурними об'єктами світового значення, які включені до списку Світової спадщини ЮНЕСКО. Об'єктами культурної спадщини є Собор Святої Софії, Києво-Печерська лавра та прилеглі монастирські споруди (з 1990 р.), Ансамбль історичного центру міста Львів (1998 р.), геодезична «Дуга Струве» (2005р.), Резиденція Далматинських та Буковинських митрополитів (Чернівецький національний університет імені Юрія Федьковича) (2011р.), Стародавнє місто Херсонес Таврійський та його хора (2013р.), Дерев'яні церкви Карпатського регіону України та Польщі, спільна українсько-польська номінація (2013р.). Природними об'єктами є Букові праліси Карпат та древні букові ліси Німеччини (2011р.). Біосферні заповідники «Чорноморський», «Асканія-Нова», «Карпатський», «Дунайський», «Шацький», «Деснянський», «Розточчя» та транскордонні заповідники «Дельта Дунаю» і «Східні Карпати» включені до Всесвітньої мережі резерватів ЮНЕСКО. До Репрезентативного списку нематеріальної спадщини людства входить українське декоративноорнаментальне малярство, а саме петриківський розпис. Козацькі пісні Дніпропетровщини, або «козацькі пісні», - це явище виконання степових пісенних творів (українських козацьких пісень) у Дніпропетровській області, внесене до Списку нематеріальної культурної спадщини, що потребує негайної охорони (2016р.) [7].

На основі проведеного аналізу розвитку галузі туризму можна сказати, що в Україні відбуваються скорочення обсягів туристичного потоку та зниження темпів зростання галузі туризму. Ці тенденції пов'язані з такими проблемами:
- соціальна та політична нестабільність у країні, анексія АР Крим, воєнні дії на території України, які негативно вплинули на загальний розвиток національної економіки та розвиток галузі туризму зокрема;

- відсутність скоординованої та ефективної політики щодо підвищення міжнародного іміджу країни та просування національного туристичного продукту України на світовий ринок;

- незадовільний стан дорожнього покриття й транспортного сполучення між регіонами України;

- низький рівень якості обслуговування клієнтів порівняно зі світовими стандартами, що зумовлене загальною кваліфікацією обслуговуючого персоналу та низьким рівнем культури менеджменту туристичної галузі;

- неефективне використання культурно-історичних та рекреаційних ресурсів туристичної галузі, незадовільний екологічний стан курортів.

Основні напрями розвитку галузі туризму визначено у Розпорядженні Кабінету Міністрів України «Стратегія розвитку туризму та курортів на період до 2026 року». У Стратегії визначено, що, незважаючи на ресурсну забезпеченість та безмежні потенційні туристичні можливості нашої країни, нині вона не має можливості конкурувати 3 розвинутими туристичними державами [8].

На основі Стратегії розвитку туризму та курортів на період до 2026 року нами запропоновано основні напрями розвитку туристичної галузі, а саме послідовна, продумана та цілеспрямована політика держави для розвитку галузі туризму. Туризм, відповідно до Закону України «Про туризм», $є$ одним із пріоритетних напрямів розвитку економіки України, тому необхідно розробити стратегію розбудови туристичної галузі країни відповідно до європейських стандартів та з урахуванням світового досвіду; покращити стан матеріально-технічної бази туристичної галузі; сфор- 
мувати рекламно-інформаційне забезпечення (поширення інформації про туристичні можливості України у світі, підвищення іміджу країни на світовому туристичному ринку); підвищити ефективність туристичних зв'язків України з іншими країнами; підвищити кваліфікацію спеціалістів та залучити приватні інвестиції в галузь туризму шляхом надання правових гарантій інвесторам та страхування від комерційних ризиків.

Висновки. Отже, на сучасному етапі розвитку туризм, пов'язаний із виїздом громадян України за кордон, розвивається швидкими темпами, що певним чином пов'язане з безвізовим режимом. Проте міжнародний туристичний потік до України характеризується різким зменшенням обсягів міжнародних туристів та зниженням темпів розвитку туристичної діяльності, що пов'язане 3 такими проблемами, як соціальна та політична нестабільність у країні, яка негативно вплинула на загальний розвиток національної економіки та на розвиток галузі туризму зокрема; відсутність ефективної політики щодо підвищення міжнародного іміджу України, незадовільний стан дорожнього покриття та транспортного сполучення між регіонами України, низький рівень якості обслуговування клієнтів порівняно зі світовими стандартами, що зумовлене загальною кваліфікацією обслуговуючого персоналу та низьким рівнем культури менеджменту туристичної галузі. Отже, запропонована стратегія розвитку туристичної галузі України базується на покращенні стану матеріально-технічної бази туристичної галузі; формуванні рекламно-інформаційного забезпечення (поширення інформації про туристичні можливості України у світі, підвищення іміджу країни на світовому туристичному ринку); підвищенні ефективності туристичних зв'язків України з іншими країнами; підвищенні кваліфікації спеціалістів та залученні приватних інвестицій в галузь туризму шляхом надання правових гарантій інвесторам та страхування від комерційних ризиків. Відповідно до європейських стандартів та 3 огляду на світовий досвід реалізація запропонованої стратегії дасть змогу організувати сучасну туристичну інфраструктуру, мати доступ до послуг у сфері туризму, можливість надавати інформацію про туристичні ресурси України у світовому просторі; надавати населенню можливість щодо працевлаштування шляхом створення додаткових робочих місць, що, відповідно, підвищить конкурентоспроможність національних туристичних послуг, а це підвищить якість життя населення, забезпечить економічне зростання за необхідної екологічної безпеки в країні. Перспективами подальших наукових досліджень є визначення ступеня впливу чинників, що впливають на вибір місця відпочинку туристами, та побудова моделі для оцінювання прогнозних масштабів туристичного потоку з урахуванням цих чинників.

\section{Список використаних джерел:}

1. Про туризм : Закон України від 4 листопада 2018 р. Відомості Верховної Ради. № 31. Cт. 241. URL: http://zakon.rada.gov.ua/laws/show/324/95-\%D0\%B2\%D1\%80 (дата звернення: 11.02.2020).

2. Пуцентейло П.Р. Економіка і організація туристично-готельного підприємництва : навчальний посібник. Київ : Центр учбової літератури, 2007. 344 с.

3. Офіційний сайт Державної служби статистики України. URL: http://www.ukrstat.gov.ua (дата звернення: 01.02.2020).

4. Офіційний сайт Всесвітньої організації туризму. URL: http://www2.unwto.org/ru (дата звернення: 14.02.2020).

5. Офіційний сайт Міністерства економічного розвитку та торгівлі України. URL: http://www.me.gov.ua/?lang=uk-UA (дата звернення: 12.02.2020).

6. Про Державний бюджет України : Закон України від 22 грудня 2011 року. Дата оновлення: 13 грудня 2018 року. Відомості Верховної Ради. URL: https://zakon.rada.gov.ua/laws/show/80-19 (дата звернення: 01.02.2020).

7. Офіційний сайт Міністерства культури України. URL: http://mincult.kmu.gov.ua/control/uk (дата звернення: 01.02.2020).

8. Про схвалення Стратегії розвитку туризму та курортів на період до 2026 року : Розпорядження Кабінету Міністрів України. URL: http://zakon.rada.gov.ua/laws/show/168-2017-\%D1\%80 (дата звернення: 01.02.2020).

9. Офіційний сайт Міністерства закордонних справ України. URL: https:/mfa.gov.ua/ua/page/open/id/639 (дата звернення: 01.02.2020).

10. Домбровська С.М. Державне регулювання туристичної галузі України : монографія. Харків : НУЦЗУ, 2016. 196 c.

11. Гуткевич С.О. Привабливість Українських Карпат: сільський зелений туризм : монографія. Київ : НУХТ, 2016. $293 \mathrm{c}$.

12. Мельниченко О.А. Особливості розвитку індустрії туризму в Україні : монографія. Харків : НУЦЗУ, 2017. 153 с.

13. Божко Л.Д. Нові напрями в туризмі як культурні наслідки глобалізації. Вісник Національної академії керівних кадрів культури і мистещзтв. 2015. № 4. С. 3-9. URL: http://nbuv.gov.ua/UJRN/vdakkkm_2015_4_3 (дата звернення: 01.02.2020).

14. Звіт Всесвітньої туристичної організації у 2018 році. URL: https://www.wttc.org/economic-impact/benchmarkreports/regional-results (дата звернення: 08.02.2020).

15. Охріменко А.Г. Досвід європейських країн фінансування туризму. Вісник Львівського університету. Серія: Міжнародні відносини. 2014. № 34. C. 160-167. URL: http://nbuv.gov.ua/UJRN/VLNU_Mv_2014_34_20 (дата звернення: 10.02.2020). 


\section{References:}

1. The Verkhovna Rada of Ukraine (1995), "On Tourism: Law of Ukraine of November 4, 2018", available at: http://zakon.rada.gov.ua/laws/show/324/95-\%D0\%B2\%D1\%80 (accessed: 11 February 2020).

2. Penzenteilo, P.R. (2007). Ekonomika i orhanizatsiia turystychno-hotelnoho pidpryiemnytstva [Economy and organization of tourism and hotel business]. Center for Educational Literature. Kyiv, Ukraine.

3. The State Statistics (2019), "Official site of the State Statistics Service of Ukraine about an immigration", available at: http://www.ukrstat.gov.ua (accessed: 01 February 2020).

4. The World Tourism Organization (2019), "Official Website of the World Tourism Organization", available at: www2.unwto.org/en (accessed: 14 February 2020).

5. Ministry of Economic Development and Trade of Ukraine (2019), "Oficial site of the Ministry of Economic Development and Trade of Ukraine", available at: http://www.me.gov.ua/?lang=en-UA (accessed: 12 February 2020).

6. The Verkhovna Rada of Ukraine (2011), The State Budget of Ukraine "Laws of Ukraine of December 22, 2011, December 6, 2012, March 27, 2014, December 28, 2014, December 29, 2015, December 28, 2016, February 2, 2017, December 13, 2018”, available at: https://zakon.rada.gov.ua/laws/show/80-19 (accessed: 01 February 2020).

7. Ministry of Culture of Ukraine (2019), "Official site of the Ministry of Culture of Ukraine", available at: http://mincult.kmu.gov.ua/control/en (accessed: 01 February 2020).

8. Decree of the Cabinet of Ministers of Ukraine (2017), "On Approval of the Strategy for Development of Tourism and Resorts for the Period up to 2026", available at: http://zakon.rada.gov.ua/laws/show/168-2017-\%D1\%80 (accessed: 01 February 2020).

9. Ministry of Foreign Affairs of Ukraine (2019), "Official Website of the Ministry of Foreign Affairs of Ukraine", available at: https://mfa.gov.ua/en/page/open/id/639 (accessed: 01 February 2020).

10. Dombrovskaya, S.M. (2016). Derzhavne rehuliuvannia turystychnoi haluzi Ukrainy. [State regulation of the tourist industry of Ukraine : monograph]. NUTSU Publishing House, Kharkiv, Ukraine.

11. Gutkevich, S.O. (2016). Derzhavne rehuliuvannia turystychnoi haluzi Ukrainy : monohrafia. [The attractiveness of the Ukrainian Carpathians: rural green tourism : monograph]. NUKHT Publishing House, Kyiv, Ukraine.

12. Melnichenko, O.A. (2017). Osoblyvosti rozvytku industrii turyzmu v Ukraini : monohrafiia. [Features of tourism industry development in Ukraine : monograph]. NUTSU Publishing House, Kharkiv, Ukraine.

13. Bozhko, L.D. (2015). "New directions in tourism as cultural consequences of globalization", Bulletin of the National Academy of Management Personnel of Culture and Arts [Online], available at: http://nbuv.gov.ua/UJRN/vdakkkm_2015_4_3 (accessed: 01 February 2020).

14. World Tourism Organization Report (2018), “Official site of the World Tourism Organization", available at: https://www.wttc.org/economic-impact/benchmark-reports/regional-results (accessed: 08 February 2020).

15. Okhrimenko, A.G. (2014), "The experience of European countries of tourism financing", Visnyk of Lviv National University. Series: International Relations [Online], available at: http://nbuv.gov.ua/UJRN/VLNU_Mv_2014_34_20 (accessed: 10 February 2020).

Chernenko Natalia, Zinchenko L. National Technical University of Ukraine "Igor Sikorsky Kyiv Polytechnic Institute”

\section{DEVELOPMENT OF TOURISM AS A PRIORITY SECTOR OF THE ECONOMY}

The current state of tourism development as a priority branch of the economy, was analyzes at the article. The essence of the economic category of tourism and its importance for economic development are determined. Ukraine has significant tourism potential and also has all the prerequisites for the development of domestic, inbound and outbound tourism, was noted at the article. The statistical data on the development of tourism activity of Ukraine, namely the dynamics of tourist flow of foreign citizens to Ukraine and Ukrainians who went abroad, the dynamics of direct employment of the population in the tourism sector, the dynamics of the share of the tourism industry in the GDP of Ukraine and the dynamics of the state financing of tourism are analyzed. A volume decrease of the tourist flow as well as a decreasing in the growth rate of the tourism industry during 2013-2019, was analyzed. Based on the analysis of the main indicators of tourism industry development, the directions of tourism development in Ukraine are determined. The departure of Ukrainian citizens abroad is developing at a rapid pace however; the international tourist flow to Ukraine is characterized by a sharp decrease in the volume of international tourists and a decrease in the rate of development of tourist activity. It happened because of: social and political instability in the country, lack of an effective policy to enhance the international image of Ukraine, poor condition of the road surface and transport connections between the regions of Ukraine, low quality of customer service, low culture of tourism industry management, has been explained by the authors. The development of the tourism industry of Ukraine should be based on: improvement the material and technical base of the tourism industry; drafting an advertising and information support, namely, dissemination of the information about Ukraine's tourist opportunities in the world; improving the efficiency of Ukraine's tourism connections with other countries; improving a specialist's skills and bringing in private investments into tourism industry by providing legal guarantees to investors and insurance against commercial risks, were emphasized in the article.

Key words: tourism industry, tourist flows, influence factors, tourism activity, directions of tourism industry development.

JEL classification: C13, C53, J61. 